\title{
超健康高齢者の心理的特徵について
}

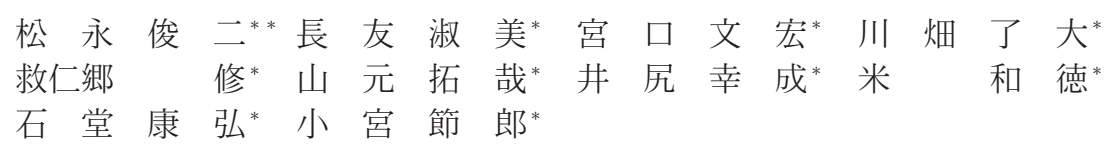

\section{Psychological Characteristics in Super-healthy Elders}

Shunji Matsunaga**, Yoshimi Nagatomo*, Fumihiro Miyaguchi*, Ryodai Kawabata*, Osamu Kunigo*, Takuya Yamamoto*, Kosei Ijiri*, Kazunori Yone*, Yasuhiro Ishidou*, and Setsuro Komiya*

80 歳以上の健康老人の心理的特徵を明らかにする目的でモーズレイ心理テストを実施した。現在む介 助を受けず自立して健康に生活している80 歳以上の超健康老人（super healthy elders） 50 名と明らか な頝椎由来の症状を有する 80 歳以上の高齢者 50 名を対象とした。頚椎由来の症状を呈する老人は 23 名 （46\%）がモーズレイ心理テストで異常がみられた。 super helthy eldersでも24例（48\%）は異常型で あったがその 88\%は転嫁順応型であった。 super helthy elders は外界から受けるストレスを適当に転嫁 させて健康を保持しているのではないかと考える。

Psychological characteristics of super healthy elders were examined with the Maudsley Personality Inventory (MPI). Two groups of subjects over 80 years of age were selected: 50 super healthy elders who still lead independent, healthy lives without receiving any aid and 50 patients with cervical symptom. The two groups were compared according to MPI. Twenty-three (46\%) subjects of the cervical symptom group were rated as abnormal pattern (introverted type, 3; emotional instability type, 8; neurosis type, 9; adaptive type, 3). Twenty-four (48\%) of the super healthy subjects were also rated as abnormal, of which 21 (88\%) were rated as adaptive type. Super healthy elders with ideal personality are able to get rid of external stress, and this may be a key to maintaining healthy lives.

Key words : super healthy elders（超健康老人), Maudsley Personality Inventory（モーズレイ心理テ スト)

はじめに

高齢になっても介護を全く必要とせず健康な生活を 送っている老人 (super-healthy elders; SHE) がい ることが知られている。本研究ではこの superhealthy elders の心理的特徵之健康との関係を検討 する目的でモーズレイ心理テスト1)を実施した。

\section{対象}

家族や周囲の人々の介護を全く受けず自立して生活 が出来, これまで外傷や感染症以外で医療を受けたこ
とのなく, また認知障害などの精神科疾患の認められ ない 80 歳以上の高齢者を super-healthy elders; SHE と定義した。この SHE50名（男性 38 名，女性 12 名）之頚椎由来の症状を有する 80 歳以上の高齢者 50 名（男性 35 名，女性 15 名）を研究対象とした。 SHE 群の年齢は 80 歳から 94 歳（平均 86.7 歳）であ り対照群である有䅡椎由来症状群は 83 歳から 91 歳 (平均 85.2 歳) である. 有䅡椎由来症状群の外来診察 時の診断は頚椎症性脊䯣症 24 名, 頚肩腕症候群 10 名, 頚椎症性神経根症 8 名, 澒椎後綐勒帯骨化症 5 名, 外 傷性澒部症 3 名であった。

\footnotetext{
* 鹿児島大学大学院運動機能修復学講座整形外科学 Department of Orthopaedic Surgery, Graduate School of Medical and Dental Sciences, Kagoshima University, Kagoshima, Japan

** 今給黎総合病院整形外科 Department of Orthopaedic Surgery, Imakiire General Hospital, Kagoshima, Japan
} 


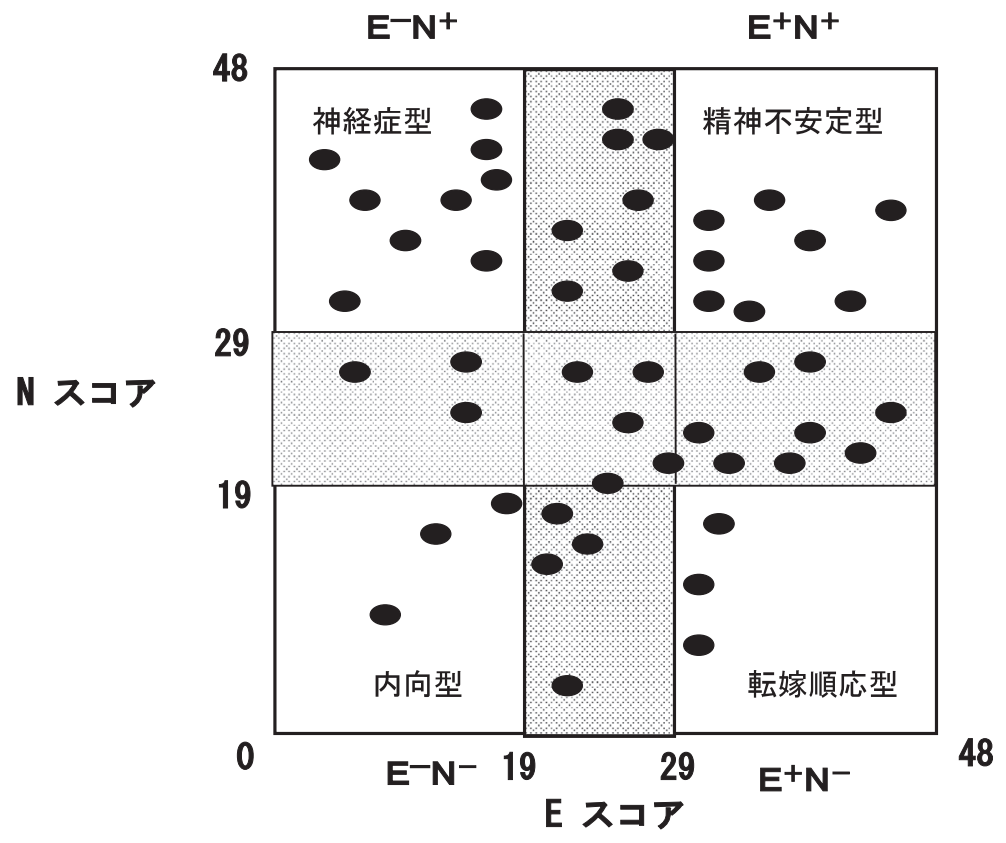

図 1 頚椎由来の症状を有する高齢者のモーズレイ心理テスト $\mathrm{N}$ スコアおよび $\mathrm{E}$ スコアが 19 点から 29 点の領域（十 字の網線領域）が正常領域である. 正常域以外の領域を $\mathrm{E}^{-} \mathrm{N}^{+}$型 (神経型), $\mathrm{E}^{-} \mathrm{N}^{-}$型 (内向型), $\mathrm{E}^{+} \mathrm{N}^{+}$型（精神 不安定型), $\mathrm{E}^{+} \mathrm{N}^{-}$型 (転嫁順応型) の 4 つに分類する.

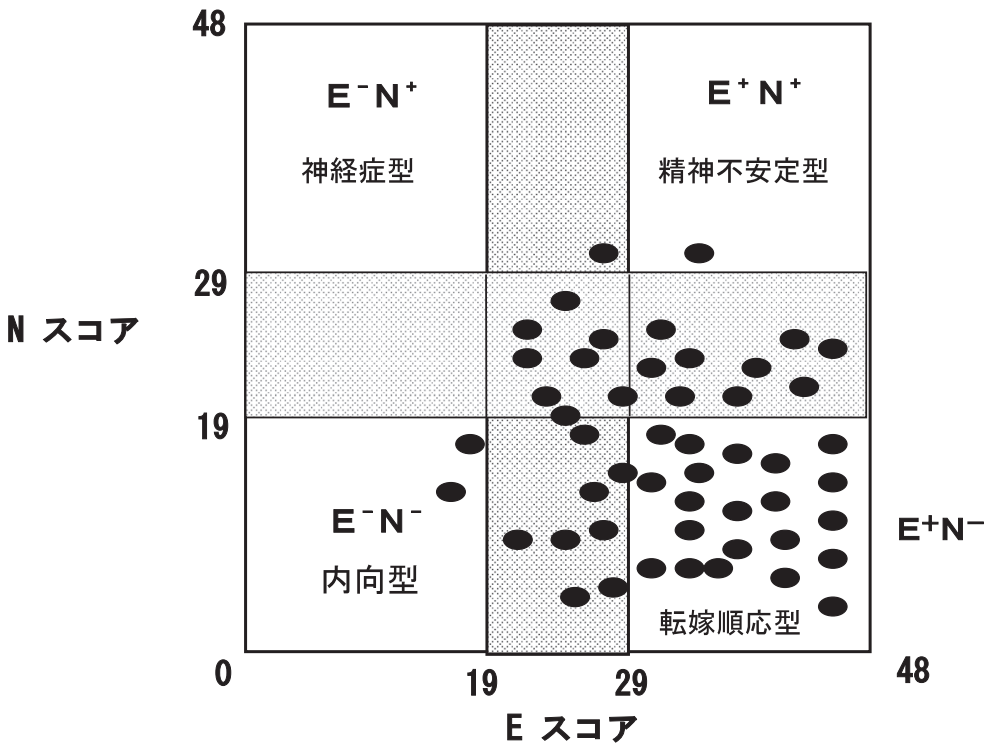

図 2 Super-healthy elders のモーズレイ心理テスト 異常領域の対象は転嫁順応型が大部分である. 


\section{方法}

全対象についてモーズレイ心理テストを実施した。 研究は臨床研究の倫理委員会の指針に基づき対象に解 析と結果の公表の同意を得た。

\section{結果}

1. 頚椎由来の症状を有する高齢者のモーズレイ心理 テスト

50 名中 27 名は正常領域であったが 23 名（46\%） は異常領域であった。異常パターンは $\mathrm{E}^{-} \mathrm{N}^{+}$型（神経 型） 9 名, $\mathrm{E}^{-} \mathrm{N}^{-}$型（内向型） 3 名, $\mathrm{E}^{+} \mathrm{N}^{+}$型（精神不 安定型） 8 名, $\mathrm{E}^{+} \mathrm{N}^{-}$型（転嫁順応型） 3 名であった (図 1 )。

2. Super-healthy elders のモーズレイ心理テスト

Super-healthy eldersにおいてもモーズレイ心理テ ストで h 異常領域が 24 名 (48\%) であった。しかし， 異常のパターンは $\mathrm{E}^{-} \mathrm{N}^{+}$型（神経型） 0 名, $\mathrm{E}^{-} \mathrm{N}^{-}$型 (内向型) 2 名, $\mathrm{E}^{+} \mathrm{N}^{+}$型 (精神不安定型) 1 名, $\mathrm{E}^{+} \mathrm{N}^{-}$ 型（転嫁順応型）21名と圧倒的に $\mathrm{E}^{+} \mathrm{N}^{-}$型（転嫁順 応型）が多いのが特徵であった（図 2 ).

\section{考察}

今回の心理テストの結果では高齢になっても理想的 な健康を維持している SHE においては転嫁順応型が 頚椎由来の症状を有する高齢者に比べ多いことがわかっ た. 研究で使用したモーズレイ心理テストは外界から 受ける種々のストレスに対する心理的反応のパターン を解析するのに有用なテストである ${ }^{3)}$. 我々は以前に
装具療法を行った側弯症患者に対してこのモーズレイ 心理テストを行い患者が種々のパターンの心理的反応 を示すことを報告した ${ }^{2)}$. 頚椎由来の症状を有する高 齢者は神経型, 内向型, 精神不安定型などの異常が多 く転嫁順応型は 3 名のみであった。 Super-healthy elders は身体的に健康であるため心理的にも正常が 多いと考えられたが実際は2 4 名 (48\%) が心理テス トで異常領域であった。しかし, Super-healthy elders 異常型の 88\%は転嫁順応型であり，この群の高 齢者は外界からのストレスに適応していることがわかっ た. 心理的ストレスは老化に関係する重要な危険因子 である. Super-healthy elders はこの心理的ストレ スを転嫁することにより種々の有害な加齢現象を回避 している可能性がある.

\section{結語}

Super-healthy elders は外界からのストレスを転 嫁順応させる心理的特徵を有することがわかった。

\section{参 考 文 献}

1) Jensen, A. R. : The maudsley personality inventory. Acta. Psychol., 14 : 314-325, 1958.

2) Matsunaga, S., et al. : Psychologic management of brace therapy for patients with idiopathic scoliosis. Spine, $30: 547-550,2005$.

3) Stonehill, E., Crisp, A. H. : Psychoneurotic characteristics of patients with anorexia nervosa before and after treatment and at follow-up 4-7 years later. J. Psychosom Res., 21 : 187-193, 1977. 